\title{
Morphology of Bertiella studeri (Blanchard, 1891) sensu Stunkard (1940) (Cestoda: Anoplocephalidae) of human origin and a proposal of criteria for the specific diagnosis of bertiellosis
}

\author{
María Teresa Galán-Puchades, Màrius Vicent Fuentes and Santiago Mas-Coma
}

\author{
Department of Parasitology, Faculty of Pharmacy, University of Valencia, Av. Vicent Andrés Estellés s/n, 46100 Burjassot - \\ Valencia, Spain
}

Key words: Bertiella studeri, morphology, species complex, diagnosis of bertiellosis

\begin{abstract}
Human material of an African specimen of Bertiella studeri (Blanchard, 1891), a typical intestinal cestode of monkeys, is described. Mature, postmature and gravid proglottides, and eggs, previously inadequately figured, are illustrated and photographed. The description of the species agrees with that provided by Stunkard (1940). A comparative study with other descriptions of the species is made in an attempt to clarify previous findings. The morphological differences reported in various earlier descriptions of the species suggest that $B$. studeri should be regarded as a "B. studeri species complex". Improvements are required in the descriptions of new future findings in order to clarify the specific diagnosis of human bertiellosis. Evidence suggests that a generalised diagnosis exclusively based on egg size and geographical distribution is insufficient to differentiate $B$. studeri and Bertiella mucronata (Meyner, 1895), or additional species may be affecting humans.
\end{abstract}

Human bertiellosis, recently reviewed by Denegri and Pérez-Serrano (1997), is the intestinal parasitisation by adult cestodes of the genus Bertiella Stiles et Hassall, 1902. Members of this genus are common parasites in primates, rodents, dermopterans and Australian marsupials and are the only anoplocephalids occurring in humans. Two species, Bertiella studeri (Blanchard, 1891) and Bertiella mucronata (Meyner, 1895), each with different geographic distributions, are known to parasitise humans (Denegri et al. 1998). The majority of human cases involve B. studeri, although some $B$. mucronata infections have also been reported (Denegri and Pérez-Serrano 1997).

Bertiella studeri is a parasite of monkeys in Africa and Asia. The species was described by Stunkard (1940) based on material obtained from the rhesus monkey (Macaca mulatta). Oribatid mites are the intermediate hosts of this cestode, harbouring the cysticercoid type larva. The accidental ingestion of infected mites, found in habitats associated with monkeys, results in parasitisation of the definitive host.

The lack of a complete contemporary description of specimens of $B$. studeri, from vertebrate hosts, is the cause of the persistent controversy initially recognised by Spasskii (1951). This author believed that some of the twelve descriptions compared by him differed from each other more than the comparative descriptions of $B$. studeri and B. mucronata. Currently, the lack of adequate morphological detail prevents the taxonomic differentiation of these cestodes of importance to human health.

The present study contributes to further knowledge of the morphology and morphometry of African material of human origin. Mature, postmature, and gravid proglottides and eggs are described, complemented by drawings and photomicrographs of the material analysed. A comparative analysis of previous descriptions of $B$. studeri and an evaluation of the controversy over the specific diagnosis of bertiellosis is presented.

\section{MATERIALS AND METHODS}

Specimens of B. studeri were obtained from a human case of bertiellosis imported to Spain from Africa (Galán-Puchades et al. 1997a). The patient, a Spanish woman living in Kenya, had passed proglottides almost uninterruptedly for 15 months.

The faecal material, comprised of mature and gravid proglottides, was preserved in $70 \%$ ethanol for study. Several types of proglottides were manually separated under a binocular magnifying lens and stained with alcoholic chlorhydric carmine, dehydrated in a graded alcohol series, cleared with xylene and mounted in Canada balsam. Due to the marked contraction of the proglottides, they were mounted transversely.

Photographs were made with a Polyvar Reichert-Jung microscope. Measurements are given in millimetres and expressed as length by width with mean and number of measurements indicated in parentheses. The maturation state of the proglottis considered (mature, postmature, pregravid and gravid) corresponds to the terminology employed for other Cyclophyllidea by Mas-Coma and Galán-Puchades (1991).

\section{RESULTS}

Bertiella studeri (Blanchard, 1891) sensu Stunkard (1940)

Figs. 1-3

Description: Proglottides craspedote. Dimensions of mature (Fig. 1C) and postmature (Fig. 1D) proglottides $7.80-11.30(9.52) \times 1.43-2.55(1.76)(\mathrm{n}=4)$, of pregravid proglottides $11.26-13.92(12.69) \times 2.72-2.86$ 

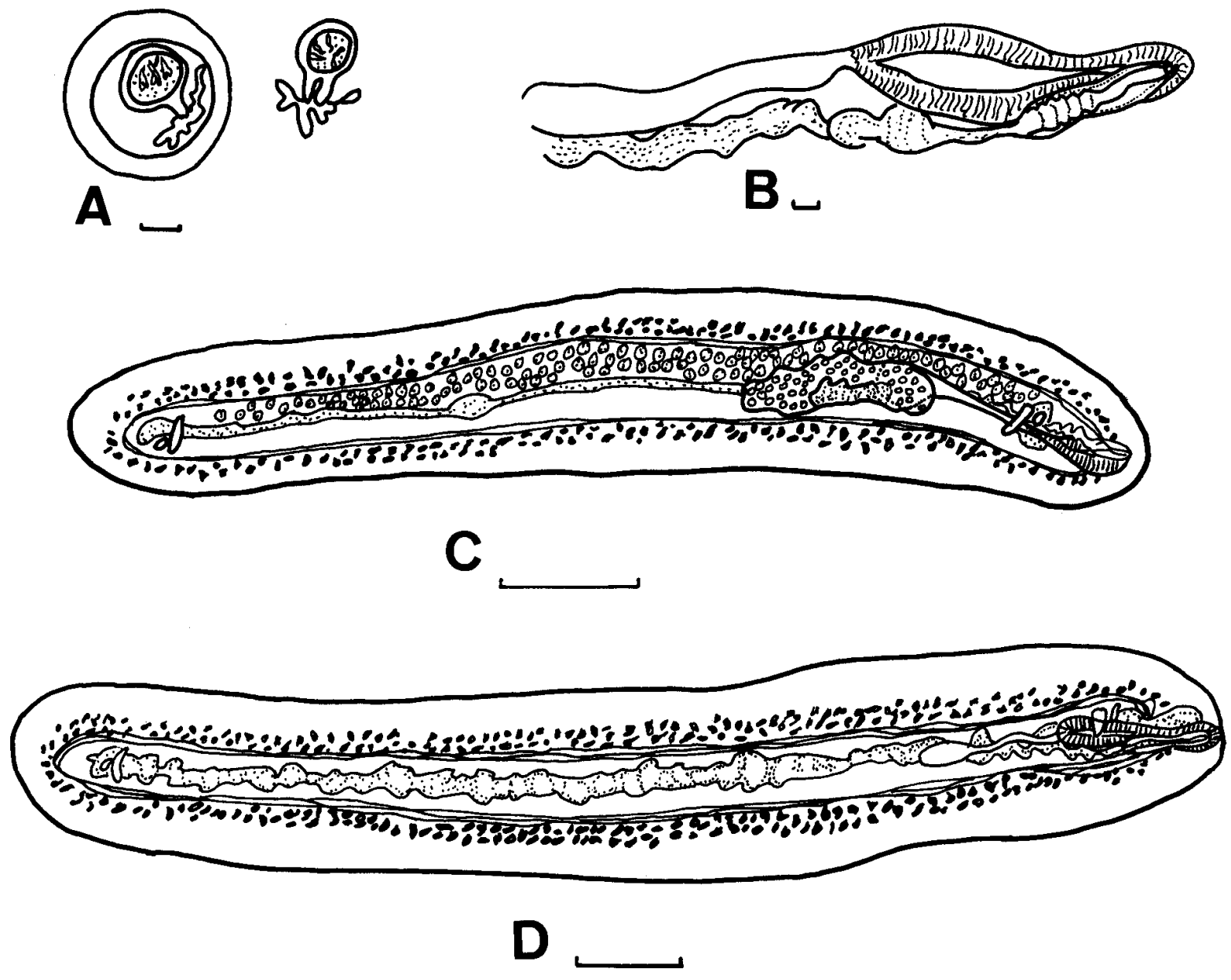

Fig. 1. Human Bertiella studeri. A - egg and pyriform apparatus; B-D - transversal views; B - cirrus sac and vagina; C - mature proglottis; D - postmature proglottis. Scale bars: A $=0.01 \mathrm{~mm} ; \mathrm{B}=0.1 \mathrm{~mm} ; \mathrm{C}, \mathrm{D}=1 \mathrm{~mm}$. (A, C, D reproduced with permission from Am. J. Trop. Med. Hyg. 56: 610-612, 1997).

(2.79) $(\mathrm{n}=3)$. Longitudinal osmoregulatory canals paired. Dorsal canal smaller than ventral; in the posterior margin of each segment, ventral canals connected by wide transverse canal whose sinuosity, depending on degree of extension, may attain width of 0.31 (Fig. 2A). Genital pores alternate irregularly. Genital atrium in middle of lateral proglottis margin; its measurements in pregravid proglottides reach $0.051 \times 0.037$. Cirrus sac thick-walled (0.02), maximum dimensions 0.28-0.48 $(0.37) \times 0.08-0.10(0.09)(\mathrm{n}=3)$ in mature proglottides (Figs. 1B, 2B) and $0.86 \times 0.14(\mathrm{n}=1)$ in pregravid proglottides, not reaching poral excretory canals. Internal seminal vesicle present. Cirrus unarmed. Testes intervascular, approximately $280(\mathrm{n}=3)$ per proglottis, occupying dorsal anterior portion of proglottis (Figs. $1 \mathrm{C}, 2 \mathrm{C})$; distributed in dorso-ventral and anteroposterior layers; testis diameter 0.068-0.094 (0.083) $\times$ $0.057-0.080(0.066)(\mathrm{n}=10)$. Vagina opens posteriorly to male pore; surrounded by layer of glandular cells with thickness 0.07 (Fig. 1B). Glandular layer extending to osmoregulatory canals, reaching dimensions of $0.60-0.63(0.61) \times 0.08-0.15(0.11)(\mathrm{n}=3)$ in mature proglottides (Fig. 2B) and 1.44-1.64 (1.54) $\times$ 0.20-0.38 $(0.28)(\mathrm{n}=3)$ in pregravid proglottides. Non-glandular portion of vagina measures $0.54-1.10(0.83) \times 0.07-0.09$ $(0.08)(\mathrm{n}=3)$ in mature proglottides and $1.10 \times 0.17(\mathrm{n}$ $=1$ ) in pregravid proglottides. Seminal receptacle oval, with dimensions $0.48-0.67(0.60) \times 0.31-0.48(0.40)(\mathrm{n}$ $=3)$; in pregravid proglottides, this reaches $1.10 \times 0.60$ $(\mathrm{n}=1)$; seminal receptacle posterior to ovary (Fig. 1C). Ovary measures 1.24-1.54 (1.40) × 0.37-0.46 (0.41) (n $=3$ ), located in poral side of centre of proglottis, composed of numerous broadly clavate lobules (Fig. 1C). Vitellarium reniform, with measurements 0.23 $0.36(0.29) \times 0.15-0.22 \quad(0.19)$. Uterus single, transverse, extending in tubular stage across middle of proglottis (Fig. 1C), posterior to testes, and in some proglottides surpassing level of osmo regulatory 

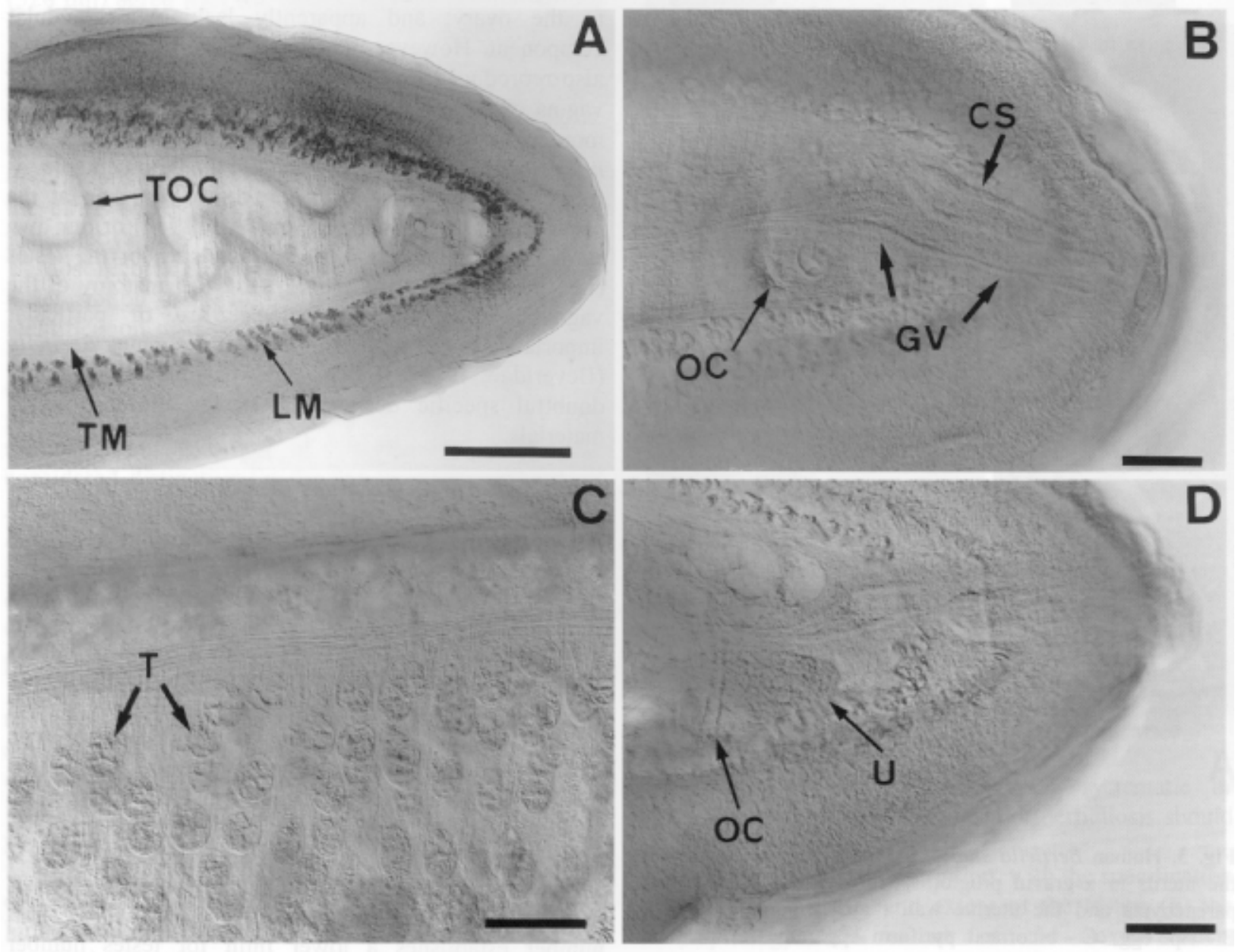

Fig. 2. Human Bertiella studeri. A - section of mature proglottis in transverse position; B-D - different transverse views of mature proglottides; B - male and female terminal genital ducts; $\mathbf{C}$ - testicular region; $\mathbf{D}$ - aporal extension of the uterus. Abbreviations: TOC - transverse osmoregulatory canal; LM - longitudinal musculature; TM - transverse musculature; $\mathrm{T}$ - testes; $\mathrm{OC}$ - osmoregulatory canals; $\mathrm{GV}$ - glandular vagina; $\mathrm{CS}$ - cirrus sac; $\mathrm{U}$ - uterus. Scale bars: $\mathrm{A}=0.5 \mathrm{~mm} ; \mathrm{B}, \mathrm{C}, \mathrm{D}=$ $0.2 \mathrm{~mm}$.

canals (Fig. 2D). As eggs conform, uterus (wall thickness was $8.5 \mu \mathrm{m})$ develops antero-posterior diverticula (Fig. 1D). In its expansion, uterus laterally surpasses osmoregulatory canals; sacciform in gravid proglottides. In latter proglottides, uterine wall (of lesser thickness) comes into contact with parenchyma which laterally and near to genital atrium ruptures, thus allowing eggs to exit through uterine pores (term coined by Baylis 1934) (Fig. 3A). Eggs spherical, 0.037-0.051 $(0.045) \times 0.037-0.046(0.044)(\mathrm{n}=15)$ in diameter (Figs. 1A, 3B). Shell 0.004-0.007 (0.0055) in thickness, albuminous layer $0.028-0.038(0.034) \times 0.027-0.036$ $(0.032)$ in diameter. Pyriform apparatus 0.019-0.028 $(0.023) \times 0.014-0.018(0.017)$, divided at apex, and terminating in two clear arms which are continuous with filaments; oncosphere 0.012-0.015 (0.013) in diameter (Figs. 1A, 3C); "heptacanthic" embryos having been detected.

\section{DISCUSSION}

\section{Comparison with previous descriptions of $B$. studeri of non-human origin}

The most complete description of B. studeri of nonhuman origin was made by Stunkard (1940), based on specimens from Indian monkeys. The overall description of human material of B. studeri in the present study agrees with Stunkard's observations, except for the following differences: (a) the number of testes (about 280 ) is slightly greater than the number reported by Stunkard (1940) (about 250); (b) the greater dimensions of the seminal receptacle, with an average of $0.6 \times 0.4$ $\mathrm{mm}$ in mature proglottides, and reaching $1.1 \times 0.6 \mathrm{~mm}$ in pregravid proglottides - versus $0.3 \times 0.2 \mathrm{~mm}$ in the material described by Stunkard (1940); (c) the absence of the partial duplication of gonadal tissue on the aporal side of the segment; (d) the presence, before the 


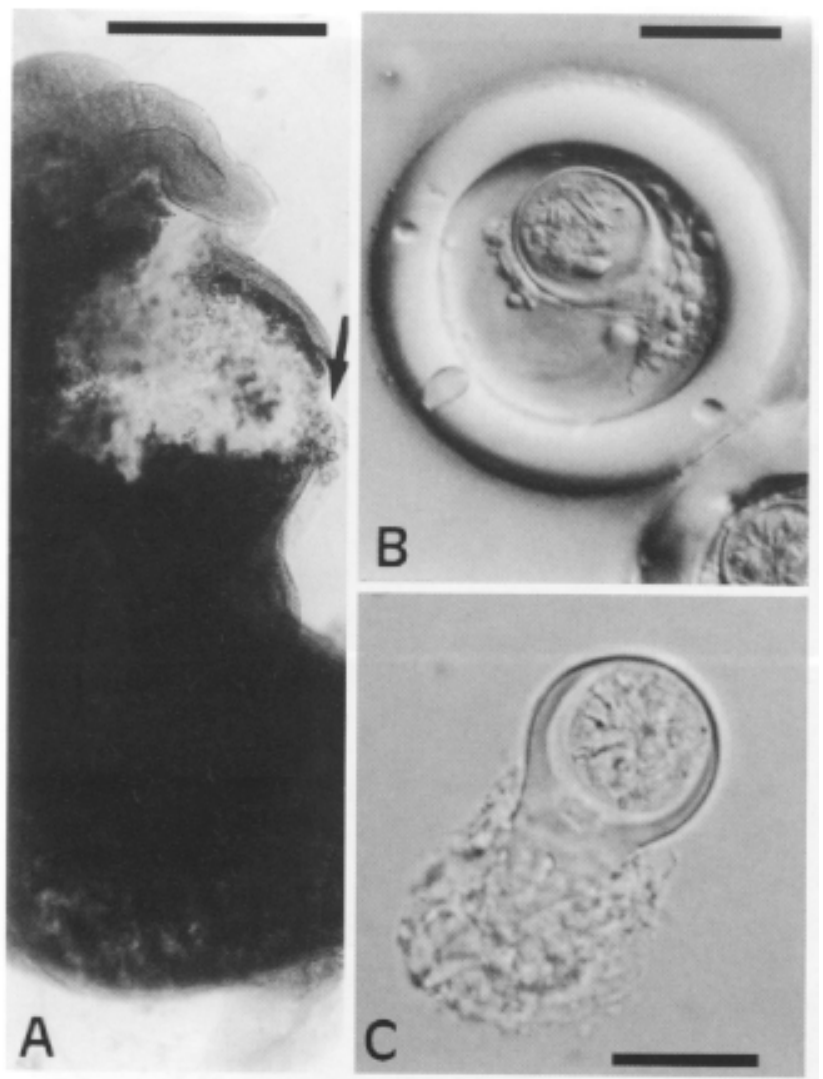

Fig. 3. Human Bertiella studeri. A - maximum extension of the uterus in a gravid proglottis, showing a rupture of the parenchyma and the uterine wall ("uterine pores") (arrow); $\mathbf{B}$ - ripe egg; $\mathbf{C}$ - bicorneal pyriform apparatus. Scale bars: $\mathrm{A}=1 \mathrm{~mm} ; \mathrm{B}, \mathrm{C}=0.018 \mathrm{~mm}$.

appearance of the typical anterior and posterior uterine evaginations, of a number of proglottides showed the young uterus to extend slightly beyond the level of the excretory canals, on both the poral and aporal side of the proglottides; and (e) the non-detection of eggs containing oncospheres with more than 7 hooks.

These differences in our material may be attributed to intraspecific variability inherent to samples of different hosts and geographical origins.

Earlier descriptions of $B$. studeri after the original report of Blanchard (1891) date from the early twentieth century and are of doubtful identity. Spasskii (1951), in a review of the genus Bertiella, based his description of the species exclusively on the work of Stunkard (1940), with reproductions of the drawings purported to be $B$. studeri made by other authors. As an example, the study of Spasskii (1951) includes a drawing of B. studeri made by Bourquin (1905), where the extent of the testicular field is much reduced compared to our material. In the material of Bourquin (1905) the testes occupy only the regions extending from the limit of the aporal excretory canals to the aporal level of the ovary. Likewise, according to the above mentioned drawing, the vagina is a long tube extending from the genital pore to the ovary, and apparently lacking a glandular component. However, the drawing by Linstow (1905), also reproduced by Spasskii (1951), shows a glandular vagina extending to the seminal duct, with dimensions more akin to those of that part of the vagina in $B$. mucronata. Furthermore, the seminal receptacle is located quite anterior to the ovary rather than at the same level as described by Stunkard (1940) or our own study. In this context, the characteristics of the testes (i.e., their number and extent), and the anatomy of the vagina and seminal receptacle, are of particular importance to the systematisation of the genus Bertiella (Beveridge 1985, 1989) - thus suggesting a rather doubtful specific designation of the aforementioned materials.

\section{Comparison with previous descriptions of $B$. studeri of human origin}

The rarity of human bertiellosis and hence the difficulties involved in obtaining human material accounts for the lack of descriptions to date of the different types of proglottides in the strobila of human origin, a fact that complicates comparative analysis with our own material. In the last 25 years only three studies of human cases provide limited morphological data (without complete morphometric details) of mature proglottides of B. studeri (Bhaibulaya 1985, Kagei et al. 1992, Ando et al. 1996). In this context, the description of the human material from Thailand (Bhaibulaya 1985) includes no measurements, though the number of testes in mature proglottides is provided (214 to 237). This number establishes a lower limit for testes number reported for the species, the upper limit being our material (280 testes). These limits logically vary and can only be estimated, for the testes are distributed in multiple layers within the proglottides, making exact counts almost impossible. Although no measurements are provided, the rest of the morphological characteristics presented by Bhaibulaya (1985) appear to coincide with our own, as deduced from the drawings made by the author of both the mature and gravid proglottides. No description of the eggs is provided.

Kagei et al. (1992) published two cases of B. studeri from North Sumatra (Indonesia). The description speaks of a weakly developed "funnel-shaped" vagina, with no mention of any glandular component, while the egg dimensions are given as 33-41 × 36-41 $\mu \mathrm{m}$. The latter values for Indonesia coincide with those reported for $B$. mucronata [36-46.1 × 36-40 $\mu \mathrm{m}$; values derived from the review by Denegri (1985)], for the eggs of $B$. studeri are considerably larger [40-48.7 × 48-62 $\mu \mathrm{m}$; values derived from Denegri (1985), Richard-Lenoble et al. (1986), Bandyopadhyay and Manna (1987) and Galán-Puchades et al. (1997)].

Ando et al. (1996) described the third human case of B. studeri, in Japan. These authors do not specify the number of testes, though the cirrus sac dimensions 
$(520 \mu \mathrm{m})$ agree with the values reported for this species by both Stunkard (1940) $(0.3-0.5 \mathrm{~mm})$ and our own $(0.37-0.86 \mathrm{~mm})$. On the other hand, these authors, while not providing actual dimensions, report the glandular portion of the vagina to be smaller than the cirrus sac; consequently, the Japanese specimens differ from the descriptions published for $B$. studeri to date, in which the cirrus sac is always found to be smaller than the glandular vagina.

Most records of human bertiellosis, in the absence of a description of the strobila, are mainly based on the identification of eggs visualised in stools or originating from ruptured gravid proglottides expelled by the patient (Galán-Puchades et al. 1997b). The morphology and particularly the dimensions of these eggs, together with the geographical origin of the material, have been considered distinctive for the specific differentiation of $B$. studeri from B. mucronata, the only other species of Bertiella reported from humans. Specifically, $B$. mucronata has smaller eggs and a geographical distribution in the New World (South America and Cuba), whereas the eggs of B. studeri are larger and the parasite is found in the Old World (Africa and Asia).

Human diagnosis of $B$. studeri from eggs often failed to report the filaments arising from the pyriform apparatus described by Stunkard (1940) which are clearly present in our material. These filaments are identified in B. studeri but not in B. mucronata, as previously noted by D'Alessandro et al. (1963). Thus, for example, Panda and Panda (1994) have drawn the egg detected in stools from a human case of B. studeri in India, with dimensions that correspond to those of the species in question, but lack filaments. Edirisinghe and Cumararajan (1976) reported that "in some eggs the protrusion of the inner shell was clearly seen, but the bicornuate arrangement was concealed by some debris". This debris may possibly have been the filaments in question. Richard-Lenoble et al. (1986) described the filaments, but Bandyopadhyay and Manna (1987), and Ando et al. (1996), did not - possibly because no such structures were observed, or because no mention of them was made. Authors should take care to verify this character in future reports.

\section{CONCLUSIONS}

A classification problem clearly exists in relation to this "B. studeri complex" of species, which would comprise different descriptions $[B$. studeri sensu Stunkard (1940), B. studeri sensu Bourquin (1905), B. studeri sensu Kagei et al. (1992), etc.)].

The problem arises from the insufficiency of morphoanatomic descriptions of the adult stages and eggs of the species. This situation is in turn exacerbated by the lack of sufficient figures and morphoanatomic details in the available descriptions.

Another important question is the systematic importance of the different morphological characteristics and the possible variations in the materials obtained from different hosts and/or geographical origins.

The generalised view that human cases imply only two species (i.e., B. studeri and B. mucronata) loses consistency when examined in the light of the literature. As has been pointed out in the Discussion, egg size may coincide with that established for B. studeri, but not so the morphology of the sexual ducts. In turn, the Indonesian cases mentioned involve a species with eggs smaller than those reported for B. studeri and coincident with those of $B$. mucronata, while the vaginal morphology does not fit either species.

In order to resolve the existing systematic or taxonomic problem, the diagnosis of bertiellosis should consider a number of criteria:

(1) Improved material description, with the specification of: (a) the number and extent of the testes; (b) the morphology and extent of the sexual ducts (dimensions of the glandular vagina and cirrus sac) and seminal receptacle; (c) the extent of the young uterus; and (d) the size and internal morphology of the eggs (characteristics of the pyriform apparatus and presence or absence of filaments).

(2) Consideration of the possibility that two or more species may be implicated in the production of human bertiellosis.

(3) In those cases where only gravid proglottides and/or eggs (but no mature proglottides) are available, an exclusively generic diagnosis appears to be indicated.

\section{REFERENCES}

ANDO K., ITO T., MIURA K., MATSUOKA H., CHINZEI Y. 1996: Infection of an adult in Mie prefecture, Japan by Bertiella studeri. Southeast Asian J. Trop. Med. Public Health 27: 200-201.

BANDYOPADHYAY A.K., MANNA B. 1987: The pathogenic and zoonotic potentiality of Bertiella studeri. Ann. Trop. Med. Parasitol. 81: 465-466.

BAYLIS H.A. 1934: On two new species of the cestode genus Bertiella, with a note on the presence of uterine pores. Ann. Mag. Nat. Hist. 14: 412-421.
BEVERIDGE I. 1985: The genus Bertiella (Cestoda: Anoplocephalidae) from Australasian mammals: new species, new records and redescriptions. Syst. Parasitol. 7: 241-289.

BEVERIDGE I. 1989: Species of Bertiella (Cestoda: Anoplocephalidae) in dermopterans and squirrels from South-East Asia. Syst. Parasitol. 14: 1-15.

BHAIBULAYA M. 1985: Human infection with Bertiella studeri in Thailand. Southeast Asian J. Trop. Med. Public Health 16: 505-507. 
BLANCHARD R. 1891: Sur les helminthes de primates antropoides. Mém. Soc. Zool. Fr. 4: 186-196.

BOURQUIN J. 1905: Cestodes de Mammifères. Le genre Bertia. Rev. Suisse Zool. 13: 415-506.

D'ALESSANDRO A., BEAVER P.C., MASI PALLARES R. 1963: Bertiella infection in man in Paraguay. Am. J. Trop. Med. Hyg. 12: 193-198.

DENEGRI G.M. 1985: Consideraciones sobre sistemática y distribución geográfica del género Bertiella (CestodaAnoplocephalidae) en el hombre $\mathrm{y}$ en primates no humanos. Neotrópica 31: 55-63.

DENEGRI G.M., BERNADINA W., PEREZ-SERRANO J., RODRIGUEZ-CAABEIRO F. 1998: Anoplocephalid cestodes of veterinary and medical significance: a review. Folia Parasitol. 45: 1-8.

DENEGRI G.M., PÉREZ-SERRANO J. 1997: Bertiellosis in man: a review of cases. Rev. Inst. Med. Trop. Sao Paulo 39: 123-127.

EDIRISINGHE J.S., CUMARARAJAN S.M. 1976: The first record of Bertiella studeri infection in a child from Sri Lanka. Ceylon Med. J. 22: 137-140.

GALÁN-PUCHADES M.T., FUENTES M.V., MAS-COMA S. 1997a: Human Bertiella studeri in Spain, probably of African origin. Am. J. Trop. Med. Hyg. 56: 610-612.

GALÁN-PUCHADES M.T., FUENTES M.V., SIMARRO P., MAS-COMA S. 1997b: Human Bertiella studeri in

Received 8 February 1999
Equatorial Guinea. Trans. R. Soc. Trop. Med. Hyg. 91: 680.

LINSTOW O. 1905: Neue Helminthen. Arch. Naturgesch. Berlin 71: 267-276.

KAGEI N., PURBA Y., SAKAMOTO O. 1992: Two cases of human infection with Bertiella studeri in North Sumatra, Indonesia. Jpn. J. Trop. Med. Hyg. 20: 166-168.

MAS-COMA S., GALÁN-PUCHADES M.T. 1991: A methodology for the morphoanatomic and systematic study of the species of the family Hymenolepididae Railliet et Henry, 1909 (Cestoda: Cyclophyllidea). Res. Rev. Parasitol. 51: 139-173.

PANDA D.N., PANDA M.R. 1994: Record of Bertiella studeri (Blanchard, 1891), an anoplocephalid tapeworm, from a child. Ann. Trop. Med. Parasitol. 88: 451-452.

RICHARD-LENOBLE D., KOMBILA M., MAGANGA M.L., AFFRE G. 1986: Bertiella infection in a Gabon-born girl. Am. J. Trop. Med. Hyg. 35: 134.

SPASSKII A.A. 1951: Anoplocephalate tapeworms of domestic and wild animals. In: K.I. Skryabin (Ed.), Essentials of Cestodology. Izd. AN SSSR, Moscow, 730 pp. (In Russian.) (English translation: Israel Program for Scientific Translations, 1961, 783 pp.).

STUNKARD H. 1940: The morphology and life history of the cestode, Bertiella studeri. Am. J. Trop. Med. Hyg. 20: 305-333.

Accepted 14 July 1999 